\title{
The Impact of Corruption on Economic Growth in OIC Countries
}

\author{
Basem Elmukhtar Ertimi ${ }^{1}$, Abulkasem dowa ${ }^{1,2}$, Elham Mohamed Albisht ${ }^{1} \&$ Basim Aboubaker Oqab $^{2}$ \\ ${ }^{1}$ School of Business, University of New England, Armidale, Australia \\ ${ }^{2}$ School of Business, Zawia university, Zawia, Libya \\ Correspondence: Basem E. Ertimi, Department of Ac Economics, School of Business, University of New \\ England, Australia. Tel: 61-46-689-7930. E-mail: beatimi@myune.edu.au
}

Received: June 10, 2016

Accepted: July 13, 2016

Online Published: August 25, 2016

doi:10.5539/ijef.v8n9p91

URL: http://dx.doi.org/10.5539/ijef.v8n9p91

\begin{abstract}
Economic growth in a country can be attributed to many variables, both positive and negative. Raising the level of human capital, openness and investment are examples of factors typically considered to have a positive impact on economic progress, while corruption is one of the factors that are often seen as detrimental to economic growth. The purpose of this study is to analyse whether the levels of perceived corruption in a cross-section of countries have affected their economic growth rates over the years 2003-2010. The study is conducted with a regression on a sample of 14 countries and eight variables for the time period in question. The models are constructed on the basis of the endogenous growth theory. Results using economic freedom index (EFI) shows that corruption has a negative impact of economic growth in the countries in question.
\end{abstract}

Keywords: corruption, economic growth, rent seeking

\section{Introduction}

The effect of corruption on economic performance has attracted researchers' attention in recent years, especially in less developed countries. This line of inquiry has mostly focused on the harmful effects of corruption on growth (Shleifer \& Vishny, 1993; Mauro, 1995; Bardhan, 1997). In fact, the World Bank (2005) identified corruption as one of the main hindrances to economic growth for the poor.

Corruption is defined by Bardhan (1997, p. 3) as 'the use of public office for private gains'. It can take on different forms, ranging from the mismanagement of the public office by bribery, extortion, fraud, embezzlement, and nepotism to patronage. It is seen as institutional issue, whether in terms of politics, economics, or individual and cultural problems (Luo, 2004).

Sincethe interpretation of corruption is highly contextual, Shleifer and Vishny (1993, p. 12) define corruption as the 'sale by government officials of government property for personal gain'. Sandholtz and Koetzle (2000, p. 23) concurred with this view and defined corruption as an 'exchange of either goods or services by government employees (bureaucrats) in return for some inducement and involving an element of impropriety'. The abuse of public power is not merely for one's personal gain, it is also for the benefit of party, tribe, class, family, and friends.

A few studies have argued that corruption can be, in fact, beneficial to economic growth, as it allows individuals and companies to circumvent an inefficient legal system (Leff, 1964; Huntington, 1968). However, the arguments of the harmful effect of corruption on growth are widely accepted. The extant literature has mostly found that corruption is inefficient, as it creates waste because of its impact on production and consumption (Johnston, 1982; Klitgaard, 1988; Rose-Ackerman, 1999; Mauro, 1998).

According to the data of GDP per capita at current prices (in US dollars) of OIC countries in 2003, the GDP per capita inMiddleEast and North Africa (MENA) countries was $\$ 8986.5$. The cumulative GDP per capita for the East Asia and Pacific countries region was \$2728. Meanwhile, the total income of the Sub-Saharan Africa region was $\$ 702.85$ GDP. South Asia, on the other hand, generated \$4640.2. The Europe and Central Asia region had a GDP per capita of $\$ 1455.75$, the Caribbean and Latin America had a GDP per capita of $\$ 1806$. Obviously, the income in both the Sub-Saharan Africa region and the Europe and Central Asia region are very low compared to the other regions. Their incomes are even less than the national income of some of the individual OIC member countries. In 2011, the GDP per capita in MENA countries was \$21362.86. In Sub-Saharan Africa, on the other 
hand, the GDP per capita was \$1502.7. In South Asia, East Asia and Pacific, Europe and Central Asia, and Latin America and the Caribbean, the GDP per capita was \$9836.2, \$6736, \$5235, and \$3408, respectively (World Bank, 2012)

For many developing countries, improving economic growth marks the cornerstone for economic policy-making. However, these countries face obstacles in achieving their targeted economic growth. One of these obstacles is corruption. Many research studies have attempted to observe the relationship between economic growth and corruption. Most studies find that corruption is growth reducing (Mauro, 1995; Shleifer et al., 1993; Aidt, 2009). According to Gray and Kaufmann (1998), public-sector corruption is the most severe obstacle for economic growth. Tanzi and Davooodi (2000) and Gupta et al. (2002) argue that corruption changes the composition of government expenditure to be less productive and, thus, determines the growth.

This paper seeks to bridge the gap in the empirical evidence by studying the relationship between corruption and economic growth in the OIC countries, as the prevalent level of corruption in these counties is very high. Having an exact relationship between corruption and economic growth, especially in these countries, seems to be a difficult task, given the ambiguity of the term corruption and its measurement. Nonetheless, empirical research that has been conducted so far, which has given new insights into the problem, in terms of encouraging a better understanding of the underlying causes of corruption, its consequences, and the ideas and approaches on possible measures to fight it.

Given the background of corruption, this paper will investigate the influence of corruption on economic growth of the countries included in this study. Deriving from the ambiguity of the effect of corruption on the economic growth and the relationship between them among the countries in question, a specific research question that can be drawn on this paper is as follows:

Does corruption have a negative impact on economic growth in OIC countries?

\section{Literature Review}

Literature on the corruption-economic growth nexus remains mixed to date. This section reviews the literature on the effect of corruption on economic growth. It includes an overview of corruption measures, as well as theories on the effect of corruption on growth, and it is followed by empirical studies based on indexes used in these specific studies. This is followed by determining the gap in this literature.

\subsection{Empirical Studies on the Effects of Corruption on Economic Growth}

In the empirical literature on economic growth, corruption is considered an important independent variable. The common form of the equation used in the empirical studies can be specified as the following:

$$
g_{t i}=\beta_{0 i t}+\beta_{1} C R_{i t}+\beta_{k} E_{k i t}+u_{i t}
$$

Where $C R$ refers to corruption, $E_{k}$ refers to the set of explanatory variables, and $u$ is the error term. The coefficient $\beta_{0}$ is the constant term; the coefficient $\beta_{1}$ is the partial impact of corruption on growth, and the coefficient $\beta_{k}$ is the set of coefficients indicating the partial impact of the explanatory variables on growth.

\subsubsection{Economic Freedom Index}

Another measure that has been used for measuring corruption is the Economic Freedom Index (EFI). The EFI is an annual index generated by the Heritage Foundation. The index measures 10 different component of economic freedom (Note 1).

According to Millor et al. (2009), 'The 10 Components of Economic of economic freedom provide a portrait of a country's economic policies and establish benchmarks by which to gauge strengths and weaknesses' (p. 2). The EFI shows that economic freedom is the key in producing an environment in which innovation and entrepreneurship can thrive, along with rapid economic growth. The scale of the index ranges from 0 to 100 . While the latter refer to most economic freedom, 0 refers no economic freedom.

Peev and Mueller (2012) examined the relationship between corruption and economic growth for 24 transition countries from 1990 to 2007. Using EFI as a proxy for corruption, they found that the more economic freedom available in a country, the higher the economic growth is experienced.

Peev and Mueller (2012) also found that high EFI in a country is a result of democratic institutions. The empirical results, furthermore, show that the most important component of economic growth affecting economic growth is freedom from corruption. An increase in corruption by one unit is associated with a decrease in economic growth by 2.76 per cent. The interpretation of this finding is that economic freedom stimulates investment in a country, which, in turn, leads to more growth. 
One of the impacts of corruption on economic growth is throughout foreign direct investment (FDI). This indirect effect of corruption has been emphasised by many studies in the literature.

Generally, economists agree that the FDI inflow will lead to an increase in economic growth. For instance, Johnson (2006) examined 90 countries from 1980 to 2002 and suggested that foreign direct investment has a positive impact on economic growth as a result of spill-over effects of technology and physical capital inflows. $\mathrm{He}$ found that the inflows of foreign direct investment boost economic growth in developing countries. According to a study done by Ray (2012) on economic effects of FDI in India from 1991 to 2011, FDI has a positive impact on economic growth. He argued that this positive relationship is that FDI improves human resources and infrastructure, develops local entrepreneurship, and creates a good environment for productive investment.

Alemu (2012) tested the relationship between corruption and FDI for 16 Asian economies from 1995 to 2009. Using the EFI as a measure of corruption, he found that corruption negatively affects economic growth. The empirical results indicate that an increase in the level of corruption by 1 per cent leads to a decrease in FDI by 9.1 per cent. According to him, the negative relationship between corruption and FDI is due to the economic uncertainty that arises from corruption and, hence, affects the confidence of investors in the market, which ultimately affects economic growth.

Another finding reported in this study, however, is that China and India experienced high levels of corruption and received a huge amount of FDI. He argued that these countries can double their FDI inflows if they reduce the level of corruption. The negative relationship highlighted in this study between corruption and FDI will ultimately affect the economic growth in these countries, given the important relationship between FDI and economic growth.

\section{Data and Methodology}

To test the relationship between economic growth and corruption, panel regression analysis is employed for selected OIC countries.

\subsection{Variables and Data Sources}

The study combines variables obtained from World Bank, United Nation's Conference on Trade and Development, and Statistical, Economic and Social Research and Training Centre for Islamic Countries to build the data set. The data set includes variables for 14 countries for the years 2003-2010. Appendix 1.

\subsubsection{The Dependent Variable}

\subsubsection{Economic Growth}

The dependent variable in this study is the growth rate of real GDP per capita (in constant 2005 dollars) during the period 2003 to 2010 . Economic growth is typically quantified by gross domestic product (all production of goods and services), or the GDP per capita (GDP divided by population). Using a measure such as GDP per capita is a simple method for researchers to compare growth across countries and over time.Data on this variable is extracted from the World Bank (World Bank, 2013).

\section{The Independent Variables}

\subsection{Corruption}

Corruption is the main variable of interest. Data on corruption is obtained from one source. The source is the Economic Freedom Index (EFI) issued by the Heritage Foundation. This index is consisted of ten economic freedoms: "Business freedom, trade freedom, monetary freedom, freedom from government, fiscal freedom, propriety rights, investment freedom, financial freedom, freedom from corruption and labour freedom" (Shabbir \& Anwar, 2007, p. 13). The index score ranges from 0 to 100. A high score on the index refers to high economic freedom (low corruption), while low scores on the index refers to low economic freedom (high corruption).

\subsubsection{Investment}

The positive effect of investment on economic growth is emphasised by many empirical studies (Levine \& Renelt, 1992; Blomstrom et al., 1996; Barro, 1997). Increase in investment in physical and human capital increases the level of GDP and thereby contributes to a positive effect on the growth rate.

This variable is obtained by calculating the gross capital formation. The calculated data is the growth rate of total of gross capital formation. Investment (gross capital formation) is taken from the World Bank Database (World Bank, 2013). 


\subsubsection{Trade Openness}

Trade is expected to positively stimulate growth. Many empirical studies claim that greater trade openness does, in fact, increase growth (Harrison, 1996; Wacziarg \& Welch, 2008; Wang \& Liu, 2006; Okuyan et al., 2012). The positive relationship is attributed mainly to that a country can adopt the best technologies, thus creating an increase in productivity. The more open an economy to the international market, the higher the rate of growth (Sachs \& Warner, 1995). The trade openness index used in this study is a measure of the growth rate of total trade (the sum of exports and imports of goods and services). This variable is obtained from the World Bank (World Bank, 2013).

\subsubsection{Foreign Direct Investment (FDI)}

Empirical studies have emphasised the positive effect of FDI on economic growth (De Mello, 1999; Wang, 2009; Chih-Chiang \& Jyun-Yi, 2008). This positive effect is due to the technology transfer and dissemination of developed countries to the less developed. The FDI affects growth directly, by increasing the stock of physical and indirectly, through the technical spill-overs.

Data on foreign direct investment in the national economies used in this study have been obtained from UNCTAD and measured by the growth rate of net inflows in current U.S. dollars (United Nations Conference on Trade and Development) reports (UNCTAD, 2013).

\subsubsection{Human Capital}

Human capital (Enrolment in secondary school) is also used as an independent variable in this study. The empirical studies emphasize that human capital has a significant positive effect on economic growth (Lucas, 1990; Bergheim, 2005; Howitt, 2005; Boughanmi, 2009). Human capital increases labour productivity and output. Furthermore, as human capital is essential for the optimal use of physical capital, the increase in human capital in the economy encourages investment in physical capital, which increases growth (Abbas, 2000).

This variable describes the number of students who enrolled in a level of education among the population of official school age for that level. This variable is obtained from the Statistical, Economic and Social Research and Training Centre for Islamic Countries (SISRIC, 2013).

\subsubsection{Government Expenditure}

Government expenditure, in some circumstances, has a positive effect on economic growth, particularly, when government is spending in public infrastructure (Bose et al., 2007; Acosta, Ormaechea, \& Morozumi, 2013). However, Government expenditure reduces economic growth by generating higher levels of taxes, and thus decreases the share of private sector. In more general terms, the use of government resources is altered to the public sector from the private sector, and most economists argue that the private sector is more efficient allocation of resources than the public sector (e.g., Jensen \& Stonecash, 2004; Cooray, 2009; Nurudeen \& Usman, 2010).

Data on government expenditure are gathered from the World Bank and it is measured as the growth rate of (General government final consumption expenditure) (World Bank, 2013).

\subsubsection{Population Growth}

Economic growth is negatively affected by the increase of population growth; this effect has proved by many empirical studies (Barro \& Sala-i-Martin, 2004; Sachs, 2008). Increase in population leads to a fall in capital per worker (Headey \& Hodge, 2009).

The variable of population growth is obtained from the growth rate of total population data from the World Bank (2013).

\subsubsection{Inflation}

In many empirical studies, the results suggest that the rate of inflation has a detrimental impact on economic growth. Inflation creates distortions, increases volatility and uncertainty, resulting in a shift towards less productive activities in order to evade the full impact of inflation and thus low growth rates (Bruno, 1998; Khan \& Senhadji, 2001; Burdekin et al., 2004; Kremer \& Bick, 2013).

Inflation data were sourced from the World Bank from 2003 to 2010 (World Bank, 2010).

\subsubsection{Dummy Variables}

Two dummy variables are created in the data set. Countries are divided according to their geographical feature. In constructing a location dummy variable, a country is given 0 if it is landlocked and 1 otherwise. The rationale 
of incorporating the dummy variable in the model is that coastal countries benefit more from trade and lower transportation costs. Voluminous Empirical growth studies utilise this dummy variable and they find that a country being landlocked has a negative effect on growth (Sachs \& Warner, 1997; Gallup et al., 1999; Dowrick \& Golley, 2004; Bosker \& Garretsen, 2009; Bidisha \& Feroz, 2012).

Another dummy represents the endowment of natural resources included in this study assigning 1 to oil producing countries and 0 otherwise. This dummy variable has been widely utilisedin the literature. It is argued by many empirical studies (Sachs \& Warner, 1997; Guetat, 2006; Akanni, 2007; Brach, 2008; Bakwena \& Bodman, 2010; Al-Malkawi \& Abdullah, 2011) that countries which are blessed with an abundance of natural resources, usually fail to have high economic growth.

Table 1 provides descriptive statistics for these variables.

Table 1. Descriptive statistics

\begin{tabular}{lccccc}
\hline Variable & $\mathbf{N}$ & Minimum & Maximum & Mean & Std. Deviation \\
\hline GDP & 112 & 1044.70 & 13766.52 & 5209.21 & 3749.50 \\
EFI & 112 & 40.60 & 66.70 & 56.22 & 5.60 \\
FDI & 112 & -4675289.39 & 83180401.13 & 14433251.57 & 17814039.17 \\
INF & 112 & -0.68 & 25.30 & 6.37 & 4.92 \\
OP & 112 & 1309021992.72 & 335289691715.97 & 71462319475.27 & 95547007734.59 \\
INV & 112 & 249855407.70 & 116693329170.51 & 22424271466.89 & 29113333235.84 \\
GE & 112 & 233945151.70 & 73550233900.00 & 11435206713.63 & 16365383422.42 \\
POP & 112 & 3150143.00 & 240676485.00 & 53465726.57 & 69955964.99 \\
SENR & 112 & 354587.00 & 19975916.00 & 4124501.04 & 4929113.65 \\
\hline
\end{tabular}

Data are obtained from World Bank, UNCTAD, and SISRIC.

Where: GDP (GDP Growth Per Capita), EFI (Economic Freedom Index), FDI (foreign direct investment), INF (inflation), OP (Openers), INV (Investment), GE (Government Expenditure), POP (Population Growth), and SENR (Human Capita, measured by Secondary School Enrolment).

Table 2 provides the correlation among the variables included in this study.

Table 2. Correlation matrix among the variables

\begin{tabular}{|c|c|c|c|c|c|c|c|c|c|c|}
\hline & RGDP & EFI & FDI & GE & $\mathrm{OP}$ & INF & & INV & POP & SENR \\
\hline RGDP & 1.0000 & & & & & & & & & \\
\hline EFI & 0.4647 & 1.0000 & & & & & & & & \\
\hline FDI & 0.5359 & 0.2955 & 1.0000 & & & & & & & \\
\hline GE & 0.5557 & 0.0777 & 0.2887 & 1.0000 & & & & & & \\
\hline $\mathrm{OP}$ & 0.6941 & 0.2130 & 0.6697 & 0.7601 & 1.0000 & & & & & \\
\hline INF & -0.0732 & -0.2025 & 0.0002 & 0.2164 & 0.0268 & 1.0000 & & & & \\
\hline INV & 0.4761 & 0.1829 & 0.0269 & 0.4142 & 0.9380 & 0.8107 & 0.2233 & 1.0000 & & \\
\hline POP2 & 0.0993 & 0.2552 & 0.3297 & -0.1135 & 0.2992 & 0.1471 & 0.0893 & 0.1713 & 1.0000 & \\
\hline SENR & -0.1547 & -0.2602 & -0.3238 & 0.2099 & 0.4498 & 0.4225 & 0.2561 & 0.6577 & -0.2423 & 1.0000 \\
\hline
\end{tabular}

Table 2 provides correlation matrix of the variables included in the study. It indicates that there are two correlation coefficients have a value greater than 0.6. Economic growth is positively associated with openness which is 0.6941 (Note 2).

\subsection{Econometric Model and Methodology}

To investigate the consequences of corruption on economic growth, panel data analysis is employed for the period 2003-2010. To achieve this end, the fixed-effects model and the first-differenced model are examined. Moreover, Panel Two-Stage Least Squares is used to increase the reliability of the estimates.

\subsubsection{The Fixed Effects Estimator}

When the individual intercepts are treated as fixed constants, which can be randomly related to the regression vectors, the resulting model is known as the fixed effect model. This study uses fixed-effects model, which 
permits the intercept to vary across countries.

One way to do this is to estimate a "fixed effects" model that gives every unit in our study its own intercept. Fixed-effect model of parameter variations identify that only the intercept term varies, not the slope coefficients, and the intercept varies only across individual countries and not overtime. A general form of the fixed-effects model is:

$$
y_{i t}=\beta_{1 i}+\beta_{2} x_{2 i t}+\beta_{3} x_{3 i t}+\ldots+\beta_{k} x_{k i t}+e_{i t} \quad t=1, \ldots . ., T
$$

The equation (1) exhibits that all behavioural differences among cross-sectional units and across time are captured by the intercept term. Inter-countries differences are captured by the fixed intercept terms. As such, unobserved factors driving the variations of country's economic growth are captured in the respective country intercept in the fixed-effects model.

Having averaged the data across time (by summing both sides of the equation 1 and dividing by $T$;

$$
\frac{1}{T} \sum_{t=1}^{T} \cdot\left(G D P_{i t}=\beta_{1 i}+\beta_{2} E F I_{i t}+\beta_{3} F D I_{i t}+\beta_{4} O P_{i t}+\beta_{5} G E_{i t}+\beta_{6} I N F_{i t}+\beta_{7} I N V_{i t}+\beta_{8} P O P_{i t}+\beta_{9} S E N R_{i t}+e_{i t}\right)
$$

The fixed effects model would be as

$$
L G D P_{i t}=\beta_{1 i}+\beta_{2} L E F I_{i t}+\beta_{3} L F D I_{i t}+\beta_{4} L I N F_{i t}+\beta_{5} L O P_{i t}+\beta_{6} L I N V_{i t}+\beta_{7} L G E_{i t}+\beta_{9} L P O P_{i t}+\beta_{9} L S E N R_{i t}+\tilde{e}_{i t}
$$

Where a subscript i refers to an individual country, where each country have different intercept term, capturing inter-country differences.

The variable LGDP is GDP per capita, LEFI is economic freedom index, LFDI is foreign direct investment, LINF is the inflation rate, LOP is trade openness, LINV is investment, LGE is government expenditure, and LPOP is population growth and LSENR human capital (secondary school enrolment over the time period 8 years in this study).

The coefficient estimates in the equation above depend only on the variation of both the dependent and explanatory variables within individuals. Therefore, in estimating the effect of corruption on growth, it is only the variation in growth and corruption over time for each individual that contributes to the estimated coefficients. The variation in growth from different individuals with different levels of corruption does not play a role (Hill et al., 2011).

\subsection{First-Differenced Model}

This model is the regression on the first-differenced data. The first difference of the natural logarithm of the variable, in this study, is approximate growth rates of the variables. It allows us to test whether the growth rate of GDP per capita is determined by the growth rate of the level of corruption, growth rate of economic freedom index, growth rate of population, growth rate of investment, growth rate of inflation, growth rate of human capital, growth rate of openness and growth rate of government expenditure (Carter et al., 2008). The first-differenced model is:

$$
\begin{gathered}
D\left(\operatorname{InGDP}_{i t}\right)=\beta_{1} D\left(\operatorname{InEFI}_{i t}\right)+\beta_{2} D\left(\operatorname{InFDI}_{i t}\right)+\beta_{3} D\left(\operatorname{InINF}_{i t}\right)+\beta_{4} D\left(\operatorname{InPOP}_{i t}\right)+\beta_{5} D\left(\operatorname{InOP}_{i t}\right)+ \\
\beta_{6} D\left(\operatorname{INV}_{i t}\right)+\beta_{7} D\left(\operatorname{InGE}_{i t}\right)+\beta_{8} D\left(\operatorname{InPOP}_{i t}\right)+\beta_{9} D\left(\operatorname{InSENR}_{i t}\right)+e_{i t} .
\end{gathered}
$$

Where $\mathrm{D}$ refers to the first-difference.

\subsubsection{Two-Stage Least Squares (2SLS)}

The endogeneity problem arising from the possibility that corruption itself can be attracted to less growth economies. The two-stage least squares estimator is also performed in this study. The two-stage least squares estimator is important because it permits us to relax the assumption that the independent variables are exogenous and hence attempts to tackle the problem of endogeneity. The 2SLS regression assumes that corruption variable is endogenous and instruments for it by lagging it by one period.

\section{Results}

\subsection{Results of the Estimated Coefficients}

In this analysis, regressions on GDP growth performed. The results from the completed regressions are displayed in Tables 3 to 5. These are fixed-effect estimator, all of which treat 84 observations after taking the first difference to exhibit the growth rate of GDP per capita and give the variables on a percentage rate. The dependent variable is GDP growth per capita from 2004 to 2010.

\subsubsection{Hausman Test}

In order to measure the magnitude of the coefficients of explanatory variables, the pooled regression with fixed 
or random effects are needed. Section 4.3 gives a brief background of the fixed effect model.

The Hausman (1978) specification test is commonly applied in the literature to determine whether the fixed or random effects specification is suitable. More specifically, the interesting question for researchers is whether there is significant correlation between regressors and unobserved individual-specific random effects. This is an essential component in the Gauss-Markov assumptions. If this assumption is violated, the model is said to be biased and inconsistent. If the correlation is not found, then the random effects model can exhibit a better result. In contrast, the random effects model will be inconsistent and the fixed effects model will be chosen (Park, 2005). Appendix 2

Section 5.1.2 is based on the results of using the EFI Index as a measure of corruption by using fixed effects. The results of the analysis for countries and years with available data for both indices are shown below:

\subsubsection{Results of the EFI Index}

In this section, the effect of the EFI Index on growth is analysed. The results are based on the fixed effect model.

Table 3 shows the result of the fixed effects model with a set of independent variables by first using the first difference of GDP per capita as a dependent variable. The results of the economic variables are reported, again based on 14 countries.

Table 3 reports the same variables included in Table 3 using two-stage least square estimators. In Table 3, the most important economic variables are DGDP, DFDI, DGE, DINV, DOP, DINF, DPOP, and DSENR.

Table 3. Regression Output (EFT)

\begin{tabular}{lcc}
\hline \multicolumn{3}{c}{$\begin{array}{c}\text { Dependent Variable is first difference of GDP per capita Growth } \\
\text { Economic Freedom Index (EFI) }\end{array}$} \\
\hline Independent Variables & \multicolumn{2}{c}{ Fixed effects (First Difference) } \\
\hline DFDI & $0.006818^{* * *}$ & $(0.0447)$ \\
DGE & -0.060288 & $(0.1468)$ \\
DINF & 0.000218 & $(0.6964)$ \\
DINV & 0.079668 & $(0.1562)$ \\
DOP & $0.263386^{* *}$ & $(0.0145)$ \\
DPOP & $-3.564607^{* *}$ & $(0.0322)$ \\
DSENR & 0.001855 & $(0.9888)$ \\
EFI & 0.000109 & $(0.1105)$ \\
\hline Observations & 84 & \\
Number of countries & 14 & \\
R-squared & 0.613434 & \\
Adjusted R-squared & 0.482500 & \\
\hline
\end{tabular}

Note. $(*),(* *)$ and $(* * *)$ represent significance at the $10 \%, 5 \%$ and $1 \%$ levels, respectively. P-values are in parentheses. Data are obtained from World Bank, UNCTAD, and SISRIC.

Population growth is also significant and negatively related to economic growth as expected, but has a lesser effect on growth in this model. When a country's population increases, this leads to a decrease in GDP growth per capita.

The trade openness coefficient (DOP) is also positively related to GDP growth in this model as expected, and it is significant at the $5 \%$ level. FDI is significant and positively affects GDP growth per capita, with a coefficient of about 0.0068 .

Based on these results, only significant variables estimated in the table above apply the fixed effects Estimator, and the results are reported in Tables 4 and 5.

Having excluded the variables that are not significant in the first table using the to the EFI Index estimation, the results show that variables included in this estimation have the anticipated sign and are all significant. The results are shown in Table 5 below. 
Table 4. Regression Output (EFT) including significant variables

\begin{tabular}{lcc}
\hline \multicolumn{3}{c}{$\begin{array}{c}\text { Dependent Variable is first difference of GDP per capita Growth } \\
\text { Economic Freedom Index (EFI) }\end{array}$} \\
\hline Independent Variables & \multicolumn{2}{c}{ Fixed effects (First Difference) } \\
\hline DFDI & $0.009222^{* * *}$ & $(0.0000)$ \\
DOP & $0.301006^{* * *}$ & $(0.0000)$ \\
DPOP & $-2.638699^{*}$ & $(0.0560)$ \\
EFI & $-0.000135^{*}$ & \\
Observations & 98 & \\
Number of countries & 14 & \\
R-squared & 0.592228 & \\
Adjusted R-squared & 0.505576 & \\
\hline
\end{tabular}

Note. $(*),(* *)$ and $(* * *)$ represent significance at the $10 \%, 5 \%$ and $1 \%$ levels, respectively. P-values are in parentheses. Data are obtained from World Bank, UNCTAD, and SISRIC.

In Table 5, the EFI variable has the expected sign and is also significant at a 5\% level, indicating that corruption has a negative effect on GDP growth per capita by the magnitude of -0.00013 . The negative impact of corruption on economic growth using this index coincides with many empirical studies (e.g., Peev \& Mueller, 2012; Alemu, 2012). All other variables also have the expected sign and are all significant.

The two-stage least squares method (2SLS) is used. The results are shown in Table 6 below:

Table 5. Regression Output (EFT) (2SLS)

\begin{tabular}{ccc}
\hline \multicolumn{3}{c}{$\begin{array}{c}\text { Dependent Variable is first difference of GDP per capita Growth } \\
\text { Economic Freedom Index (EFI) }\end{array}$} \\
\hline Independent Variables & \multicolumn{2}{c}{ Fixed effects (First Difference) } \\
\hline DFDI & $0.007204^{* *}$ & $(0.0128)$ \\
DOP & $0.203814^{* * *}$ & $(0.0000)$ \\
DPOP & $-6.609494^{* *}$ & $(0.0257)$ \\
EFI & 0.000189 & \\
Observations & 84 & \\
Number of Countries & 14 & \\
R-squared & 0.723928 & \\
Adjusted R-squared & 0.652819 & \\
\hline
\end{tabular}

Note. $(*),(* *)$ and $(* * *)$ represent significance at the $10 \%, 5 \%$ and $1 \%$ levels, respectively. P-values are in parentheses. Data are obtained from World Bank, UNCTAD, and SISRIC.

Economic variables are all significant and have the expected signs. The magnitude of the negative effect of population on GDP per capita growth in this model is greater than previous estimations for a given coefficient of -6.60. FDI and trade openness variables remain significant and have the expected sign.

The dummy variables are included in Table 6 . The results are reported below:

Table 6. Regression output variables

\begin{tabular}{|c|c|c|c|c|}
\hline \multicolumn{5}{|c|}{$\begin{array}{c}\text { Dependent Variable is first difference of GDP per capita Growth } \\
\text { Dummy variables (Included) }\end{array}$} \\
\hline & Model(D1) & & Model(D2) & \\
\hline Variable & Coefficient & (P-value) & Coefficient & (P-value) \\
\hline DFDI & $0.007569^{* * *}$ & $(0.0084)$ & $0.008426 * * *$ & $(0.0013)$ \\
\hline DOP & $0.414817 * * *$ & $(0.0000)$ & $0.407809 * * *$ & $(0.0000)$ \\
\hline DPOP & $-1.000245^{* * *}$ & $(0.0000)$ & $-1.314775^{* * *}$ & $(0.0000)$ \\
\hline EFI & $6.65 \mathrm{E}-05^{* * *}$ & $(0.0000)$ & $0.000112 * * *$ & $(0.0000)$ \\
\hline D1 & 0.000571 & $(0.2105)$ & --- & --- \\
\hline D2 & --- & --- & $-0.002015^{* * *}$ & $(0.0025)$ \\
\hline
\end{tabular}




\begin{tabular}{lcc} 
Observations & 98 & 98 \\
Number of countries & 14 & 14 \\
R-squared & 0.358064 & 0.377853 \\
Adjusted R-squared & 0.330454 & 0.351094 \\
\hline
\end{tabular}

Note. $(*),(* *)$ and $(* * *)$ represent significance at the $10 \%, 5 \%$ and $1 \%$ levels, respectively. P-values are in parentheses. Data are obtained from World Bank, UNCTAD, and SISRIC.

Table 6 presents the results of dummy variables on GDP growth per capita. With respect to the second dummy variable (D2), it is highly significant at a 5\% level. However, this variable has a negative sign which contradicts growth theory. Therefore, coastal countries tend to have lower GDP growth per capita. Growth theory emphasises that when a country is landlocked, it tends to have high levels of GDP growth compared with coastal countries (Esfahani \& Ramírez, 2003; Faye et al., 2004; Masjidi \& Lahiri, 2012).

From the results above, using the EFI Index as a measure of corruption shows a negative impact on economic growth in the countries included in the study. Human capital has a negative sign and is also not significant.

\subsection{Discussion}

As stated above, the corruption variable (EFI) has a negative coefficient in the regression. Since the level of corruption increases, this means that the greater the level of corruption perceived in a country, the lower the growth rate it experiences. It is then negatively correlated with GDP growth per capita.

To achieve the objective of the study, cross-country data consisting of 14 countries over eight years from 2003 to 2010 were used. Most of the existing literature finds that the relation between the level of corruption and economic growth should be negative. This was thus the expected result. To test this, regression was conducted. The Economic Freedom Index (EFI) was used as the variable accounting for corruption, and some standard economic variables in the literature were included.

In contrast to the previous research mentioned earlier, economic growth seems unaffected by the human capital; the variable for education turns out to be insignificant during this time period. There is thus no linear relationship between human capital and GDP growth. This does not imply that the level of human capital is not an important determinant of economic growth; most empirical studies conclude that a higher level of human capital implies more skilled workers and thus a higher level of productivity (Lucas, 1990; Bergheim, 2005; Howitt, 2005). It is more likelythat this effect has been hidden by other variables in the regressions, or the secondary school enrolment rate variable is not an accurate estimation of the level human capital. A suggestion would be to instead include a variable accounting for the expenditures on higher education or R\&D. Barro (1997) argues that a high level of human capital enhances the possibility of taking advantage of new technologies. This would then mean that a country with a high level of corruption, and thus lower levels of education, would struggle more to engage new technologies. This in turn hurts productivity and economic growth. Moreover, the results obtained from using the EFI Index show a negative effect of this variable on economic growth in the countries included.

Perhaps a macro study like the one conducted here is too broad to prove the negative effects of corruption. Despite this, the study is still convinced that low levels of corruption are required for countries to achieve justifiable economic growth.

\section{Conclusion}

The objective of this paper was to test whether the level of perceived corruption in the countries under study had a negative impact on economic growth.

The results were to some extent divergent from the predictions made based on theory and previous research. In the regressions conducted in this study, the use of the EFI Index as a measure of corruption in the regression indicated a negative impact on economic growth in the countries included. It was concluded that corruption contributed negatively to economic growth. Further, by comparing the results of the different regressions, looking at the correlation matrix, it was found that there was a negative correlation between the corruption variable (for EFI index) and economic growth. This correlation was negative; the lower the level of corruption the higher that of economic growth. Countries with lower annual economic growth included in this study had in general lower levels of corruption between 2003 and 2010. This study assumed that some other factors drove economic growth, and that corruption did not present as a strong enough force to counteract it.

Dummy variables were introduced with the purpose of distinguishing oil and non-oil producing countries, as well as landlocked and coastal countries, since there appeared to be some yet undetermined factors affecting 
growth in these countries. However, dummy variable (landlocked) was found to be significant, thereby contradicting the theory in this area.

\section{References}

Abbas, Q. (2000). The role of human capital in economic growth: A comparative study of pakistan and india. Pakistan Development Review, 39(4), 451-469.

Acosta, O. S., \& Morozumi, A. (2013). Can a government enhance long-run growth by changing the composition of public expenditure? International Monetary Fund, IMF Working Papers: 13/162, 2013.

Aidt, T. S. (2009). Corruption, institutions, and economic development. Oxford Review of Economic Policy, 25(2), 271-291. http://dx.doi.org/10.1093/oxrep/grp012

Akanni, O. P. (2007). Oil wealth and economic growth in oil exporting African countries (Vol. 170). African Economic Research Consortium.

Alemu, A. M. (2012). Effects of Corruption on FDI Inflow in Asian Economies. Seoul Journal of Economics, 25(4), 387-412.

Al-Malkawi, H. N., \& Abdullah, N. (2011). Finance-Growth Nexus: Evidence from a Panel of MENA Countries. International Research Journal of Finance and Economics, 63, 129-139

Bakwena, M., \& Bodman, P. (2010). The Role of Financial Development in Natural Resource Abundant Economies: Does the Nature of the Resource Matter? Botswana Journal of Economics, 7(11), 16-31.

Bardhan, P. K. (1997). Corruption and development: A review of issues. Journal of Economic Literature, 35(3), 1320-1346.

Barro, R. J. (1997). Determinants of economic growth: A cross-country empirical study. Cambridge: The MIT Press.

Barro, R., \& Sala-i-Martin, X. (2004). Economic Growth (2nd ed.). Cambridge, Mass: MIT Press.

Bergheim, S. (2005). Human Capital is the Key to Growth: Success Stories and Polices for 2020. Deutsche Bank Research, Current Issues, August 1, 2005, Frankfurt am Main, Germany. http://dx.doi.org/10.2139/ssrn.774825

Bidisha, L., \& Feroz, K. M. (2012). Landlocked countries. Journal of Economic Integration, 27(4), 505. http://dx.doi.org/10.11130/jei.2012.27.4.505

Bose, N., Haque, M. E., \& Osborn, D. R. (2007). Public expenditure and economic growth: A disaggregated analysis for developing countries. The Manchester School, 75(5), 533-556. http://dx.doi.org/10.1111/j.1467-9957.2007.01028.x

Bosker, M., \& Garretsen, H. (2009). Economic development and the geography of institutions. Journal of Economic Geography, 9(3), 295-328. http://dx.doi.org/10.1093/jeg/lbn047

Boughanmi, A., \& I. S. C. A. E. (2009). Human capital and economic growth. The Business Review, Cambridge, 13(2), 252-259.

Bruno, M. (1998). Inflation crisis and long-run growth. Journal of Monetary Economics, 41(1), 3-26. http://dx.doi.org/10.1016/S0304-3932(97)00063-9

Burdekin, R. C. K., Denzau, A. T., Keil, M. W., Sitthiyot, T., \& Willett, T. D. (2004). When does inflation hurt economic growth? Different nonlinearities for different economies. Journal of Macroeconomics, 26(3), 519-532. http://dx.doi.org/10.1016/j.jmacro.2003.03.005

Cooray, A. (2009). Government expenditure, governance and economic growth. Comparative Economic Studies, 51(3), 401-418. http://dx.doi.org/10.1057/ces.2009.7

De Mello, L. R. (1999). Foreign direct investment-led growth: Evidence from time series and panel data. Oxford Economic Papers, 51(1), 133-151. http://dx.doi.org/10.1093/oep/51.1.133

Dowrick, S., \& Golley, J. (2004). Trade openness and growth: Who benefits? Oxford Review of Economic Policy, 20(1), 38-56. http://dx.doi.org/10.1093/oxrep/grh003

Esfahani, H. S., \& Ramírez, M. T. (2003). Institutions, infrastructure, and economic growth. Journal of Development Economics, 70(2), 443-477. http://dx.doi.org/10.1016/S0304-3878(02)00105-0

Faye, M. L., McArthur, J. W., Sachs, J. D., \& Snow, T. (2004). The challenges facing landlocked developing countries. Journal of Human Development, 5(1), 31-68. http://dx.doi.org/10.1080/14649880310001660201 
Gallup, J. L., Sachs, J. D., \& Mellinger, A. D. (1999). Geography and economic development. International Regional Science Review, 22(2), 179-232. http://dx.doi.org/10.1177/016001799761012334

Gray, C. W., \& Kaufmann, D. (1998). Corruption and development. Finance and Development, 35(1), 7-10.

Guetat, I. (2006). The effects of corruption on growth performance of the MENA countries. Journal of Economics and Finance, 30(2), 208-221. http://dx.doi.org/10.1007/BF02761487

Gupta, S., Davoodi, H., \& Alonso-Terme, R. (2002). Does corruption affect income inequality and poverty? Economics of Governance, 3(1), 23-45. http://dx.doi.org/10.1007/s101010100039

Harrison, A. (1996). Openness and growth: A time-series, cross-country analysis for developing countries. Journal of Development Economics, 48(2), 419-447. http://dx.doi.org/10.1016/0304-3878(95)00042-9

Hausman, J. A. (1978). Specification tests in econometrics. Econometrica: Journal of the Econometric Society, 1251-1271. http://dx.doi.org/10.2307/1913827

Headey, D. D., \& Hodge, A. (2009). The effect of population growth on economic growth: A meta-regression analysis of the macroeconomic literature. Population and Development Review, 35(2), 221-248. http://dx.doi.org/10.1111/j.1728-4457.2009.00274.x

Hill, R. C., Griffiths, W. E., \& Lim, G. C. (2011). Principles of Econometrics (4th ed.). Wiley Global Education.

Howitt, P. (2005). Health, human capital and economic growth: A Schumpeterian perspective. Health and economic growth: Findings and policy implications, pp. 19-40.

Huntington, S. (1968). Political Order in Changing Societies. New Haven: Yale University Press.

Jensen, P. H., \& Stonecash, R. E. (2004). The efficiency of public sector outsourcing contracts: A literature review. Melbourne Institute of Applied Economic and Social Research. http://dx.doi.org/10.2139/ssrn.625461

Johnston, M. (1982). Political corruption and public policy in America. Monterey, CA: Brooks/Cole Publishing Company.

Khan, M. S., \& Ssnhadji, A. S. (2001).Threshold effects in the relationship between inflation and growth. IMF Staff Papers, 1-21.

Klitgaard, R. E., \& Klitgaard, R. (1988). Controlling corruption. Univ of California Press.

Kremer, S., \& Bick, A. (2013). Inflation and growth: New evidence from a dynamic panel threshold analysis. Empirical Economics, 44(2), 861-878. http://dx.doi.org/10.1007/s00181-012-0553-9

Kufs, C. (2011). Stats with Cats: The Domesticated Guide to Statistics, Models, Graphs, and Other Breeds of Data Analysis. Wheatmark, Inc.

Leff, N. H. (1964). Economic development through bureaucratic corruption. American Behavioral Scientist, 8(3), 8-14. http://dx.doi.org/10.1177/000276426400800303

Levine, R., \& Renelt, D. (1992). A sensitivity analysis of cross-country growth regressions. The American Economic Review, 942-963.

Lucas, R. E. (1990). Why doesn't capital flow from rich to poor countries? The American Economic Review, 80(2), 92-96.

Masjidi, F. K., \& Lahiri, B. (2012). Landlocked countries: A way to integrate with coastal economies. Journal of Economic Integration, 27(4), 505-519. http://dx.doi.org/10.11130/jei.2012.27.4.505

Mauro, P. (1995). Corruption and growth. The Quarterly Journal of Economics, 110(3), 681-712. http://dx.doi.org/10.2307/2946696

Mauro, P. (1997). The effects of corruption on growth, investment and government expenditure: A cross-country analysis. In K. A. Elliott (Ed.), Corruption and the global economy (pp. 83-107). Washington, DC: Institute for International Economics.

Mauro, P. (1998). Corruption and the composition of government expenditure. Journal of Public Economics, 69(2), 263-279. http://dx.doi.org/10.1016/S0047-2727(98)00025-5

Nurudeen, A., \& Usman, A. (2010). Government expenditure and economic growth in Nigeria, 1970-2008: A disaggregated analysis. Business and Economics Journal, 2010, 1-11.

OIC Permanent Delegation. (2013). SISRIC. Retrieved from http://www.oic-un.org/about/Charter.htm 
Park, H. M. (2005). Linear regression models for panel data using SAS, Stata, LIMDEP, and SPSS. Indiana University.

Peev, E., \& Mueller, D. C. (2012). Democracy, Economic Freedom and Growth in Transition Economies. Kyklos, 65(3), 371-407. http://dx.doi.org/10.1111/j.1467-6435.2012.00543.x

Ray, D. S. (2012). Impact of Foreign Direct Investment on Economic Growth in India: A Co integration Analysis. Advances in Information Technology and Management, 2(1), 187-201.

Rose-Ackerman, S. (1999). Corruption and Government: Causes, Consequences and Reform. London: Cambridge University Press. http://dx.doi.org/10.1017/CBO9781139175098

Sachs, J. (2008). Common wealth: Economics for a crowded planet. London: Penguin Press

Sachs, J. D., \& Warner, A. M. (1997). Sources of slow growth in African economies. Journal of African economies, 6(3), 335-376. http://dx.doi.org/10.1093/oxfordjournals.jae.a020932

Sandholtz, W., \& Koetzle, W. (2000). Accounting for corruption: Economic structure, democracy, and trade. International Studies Quarterly, 44(1), 31-50. http://dx.doi.org/10.1111/0020-8833.00147

Shabbir, G., \& Anwar, M. (2007). Determinants of corruption in developing countries. The Pakistan Development Review, 751-764.

Shleifer, A., \& Vishny, R. W. (1993). Corruption. The Quarterly Journal of Economics, 108(3), 599-617. http://dx.doi.org/10.2307/2118402

Tanzi, V., \& Davoodi, H. (2000). Corruption, growth, and public finances.

UNCTAD. (2013). FDI/TNC database. Retrievedfrom http://www.unctad.org/fdistatistics

Wacziarg, R., \& Welch, K. H. (2008). Trade liberalization and growth: New evidence. The World Bank Economic Review, 22(2), 187-231. http://dx.doi.org/10.1093/wber/lhn007

Wang, F., \& Liu, C. (2006). Trade openness and economic growth. International Economics and Finance Journal, 1(1), 1-12.

Wang, M. (2009). Manufacturing FDI and economic growth: Evidence from Asian economies. Applied Economics, 41(8), 991-1002. http://dx.doi.org/10.1080/00036840601019059

World Bank. (2013). World Development Indicators. Retrieved March 21, 2011 from http://data.worldbank.org/indicator

\section{Notes}

Note 1 . The 10 components are as follows:

- $\quad$ Limited government (government spending, fiscal freedom );

- $\quad$ Regulatory efficiency (business freedom, labour freedom, monetary freedom);

- Rule of law (freedom from corruption, property rights); and

- Open markets (investment freedom, trade freedom, and financial freedom) (Heritage Foundation, 2013).

Note 2. Any value greater than 0,6 is considered to be high, which can be obtained by Looking at the square of the correlation coefficient (R-squared). The R-Squared is an estimate of the proportion of variance in the dependent variable that is attributable to the explanatoryvariable (s). This is commonly used to interpret the strength between the variables and comparing alternative statistical models. For instance, the correlation coefficient between the values of about -0.3 and +0.3 make up less than 9 percent of the variance in the relationship between the two variables that may indicate weak or non-existent relationship. Values between -0.3 and -0.6 or +0.3 and +0.6 accounts for 9 percent to 36 percent of the variance, which may indicate a weak to moderately strong relationship. Values between -0.6 and -0.8 or +0.6 and +0.8 is 36 percent to 64 percent of the variance, which may indicate a moderately strong relationships. Values between -0.8 and -1.0 or +0.8 and +1.0 is more than 64 percent of the variance, which may indicate a very strong relationship (Kufs, 2011). 


\section{Appendix 1. List of OIC countries included in the regression}

\begin{tabular}{ll}
\hline Malaysia & Albania \\
Morocco & Bangladesh \\
Pakistan & Cameroon \\
Syria & Indonesia \\
Tajikistan & Jordan \\
Tunisia & Kazakhstan \\
Turkey & Kyrgyzstan \\
\hline
\end{tabular}

\section{Appendix 2. Hausman test results}

Our Null hypothesis in the test is:

$H_{0}$ : The unobserved effect is uncorrelated with the independent variables;

$H_{1}$ : The unobserved effect is correlated with the independent variables.

The Hausman test results from E-views 7.0

\begin{tabular}{lc}
\hline Chi-Sq. Statistic & $20.252170^{* *}$ \\
P-value & 0.0164 \\
\hline
\end{tabular}

$* * *, * *$, and $*$ denote the 1,5 and 10 precent level of significance, respectively.

The test result has p-value equals of 0.01 , which is below to the chosen significance level, 0.05 . Hence, the null hypothesis is rejected. The drawn conclusion is that the random effects estimator is inconsistent, and fixed-effect model should be employed.

\section{Copyrights}

Copyright for this article is retained by the author(s), with first publication rights granted to the journal.

This is an open-access article distributed under the terms and conditions of the Creative Commons Attribution license (http://creativecommons.org/licenses/by/4.0/). 